\title{
Perineuronal Nets Enhance the Excitability of Fast-Spiking Neurons
}

\author{
Timothy S. Balmer
}

DOI:http://dx.doi.org/10.1523/ENEURO.0112-16.2016

Grass Laboratory, Marine Biological Laboratory, Woods Hole, Massachusetts 02543

\section{Visual Abstract}
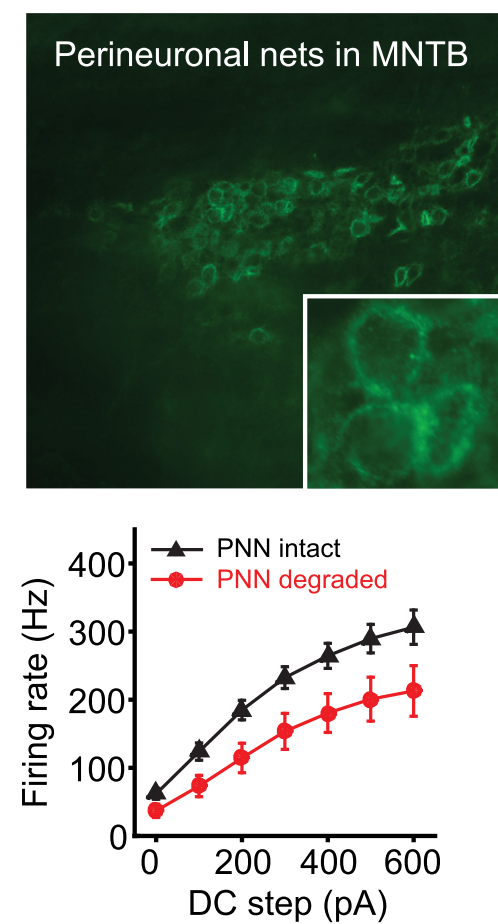

PNN intact

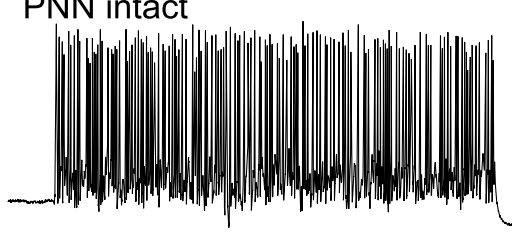

PNN degraded
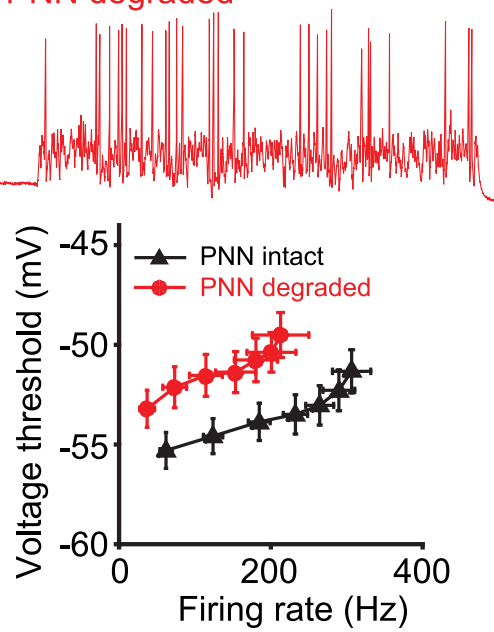

Perineuronal nets (PNNs) are specialized complexes of extracellular matrix molecules that surround the somata of fast-spiking neurons throughout the vertebrate brain. PNNs are particularly prevalent throughout the auditory brainstem, which transmits signals with high speed and precision. It is unknown whether PNNs contribute to the fast-spiking ability of the neurons they surround. Wholecell recordings were made from medial nucleus of the trapezoid body (MNTB) principal neurons in acute brain slices from postnatal day 21 (P21) to P27 mice. PNNs were degraded by incubating slices in chondroitinase $\mathrm{ABC}(\mathrm{ChABC})$ and were compared to slices that were treated with a control enzyme (penicillinase). ChABC treatment did not affect the ability of MNTB neurons to fire at up to 1000 $\mathrm{Hz}$ when driven by current pulses. However, $f-I$ (frequency-intensity) curves constructed by injecting Gaussian white noise currents superimposed on DC current steps showed that ChABC treatment reduced the gain of spike output. An increase in spike threshold may have contributed to this effect, which is consistent with the observation that spikes in ChABC-treated cells were delayed relative to control-treated cells. In addition, parvalbumin-

\section{Significance Statement}

Perineuronal nets (PNNs) are extracellular matrix specializations that surround the somata of fast-spiking inhibitory neurons in most areas of the brain. Although PNN development correlates with the restriction of plasticity and their disruption causes enhancement of plasticity in vivo, it is unclear how PNNs affect the neurons they surround. In the present study, mature neurons were stimulated with fluctuating currents to measure their input/output functions after degradation of PNNs with the enzyme chondroitinase. Both the medial nucleus of the trapezoid body principal neurons and parvalbumin-expressing fast-spiking cortical interneurons treated with chondroitinase exhibited reduced excitability compared with control-treated cells. Increased spike threshold may underlie this change in gain. Thus, PNNs increase the evoked activity of fast-spiking neurons and could control plasticity by enhancing synaptic inhibition. 
expressing fast-spiking cortical neurons in $>$ P70 slices that were treated with ChABC also had reduced excitability and gain. The development of PNNs around somata of fast-spiking neurons may be essential for fast and precise sensory transmission and synaptic inhibition in the brain.

Key words: auditory brainstem; extracellular matrix; fast spiking; inhibition; perineuronal net; white noise current

\section{Introduction}

Perineuronal nets (PNNs) are specialized complexes of extracellular matrix molecules that form around the somata of neurons throughout the brain (Brückner et al., 1993; Bertolotto et al., 1996; Celio et al., 1998). PNNs are made up of an array of proteoglycans and polysaccharides that give the cell surface a strong negative charge (Seeger et al., 1994; Morawski et al., 2004, 2015). In particular, PNNs tend to surround fast-spiking neurons (Blosa et al., 2013; Sonntag et al., 2015). Whether this negatively charged PNN coat contributes to fast-spiking activity is unclear.

Current understanding of how PNNs contribute to brain processes comes largely from studies in which PNNs are degraded enzymatically. Disruption of PNNs reactivates plasticity in the adult visual cortex (Pizzorusso et al., 2002, 2006; Carulli et al., 2010; Vorobyov et al., 2013), promotes collateral sprouting in the denervated brainstem (Massey et al., 2006), and allows the recovery of spinal cord function after injury (Galtrey et al., 2007; García-Alías et al., 2009). There are several hypothesized mechanisms through which the degradation of PNNs may control plasticity in mature brains. PNNs may prevent structural remodeling of dendrites (Mataga et al., 2004; McGee et al., 2005; Fawcett, 2009; Shen et al., 2009; Giger et al., 2010) or neurotransmitter receptor mobility and plasticity (Bukalo et al., 2001; Frischknecht et al., 2009; Kochlamazashvili et al., 2010). Given the important role that PNNs play in plasticity, surprisingly little is known about what PNNs contribute to the physiology of the neurons that they surround. It is possible that the disruption of PNNs in vivo caused a change in neuronal excitability, in addition to known structural and molecular changes that occur.

PNNs surround fast and precisely spiking neurons throughout the vertebrate brain (Härtig et al., 1992, 1999; Murakami et al., 1994; Balmer et al., 2009). PNNs are common in the auditory brainstem (Bertolotto et al., 1996;

Received May 7, 2016; accepted July 6, 2016; First published July 11, 2016.

${ }^{1}$ The author declares no competing financial interests.

${ }^{2}$ Author Contributions: T.S.B. designed research; T.S.B. performed research; T.S.B. analyzed data; T.S.B. wrote the paper.

${ }^{3}$ This research was supported by the Grass Foundation.

Acknowledgments: I thank Rebecca Mease for assistance with the white noise stimulation and analysis; Yeowool Huh for the Gad1-EGFP mice; and Larry Trussell, current and former members of the Trussell laboratory, Len Kaczmarek, Felix Schweizer, and the Grass Laboratory Director, Associate Director, and Fellows of 2014 for critical discussions throughout all stages of this project.

Correspondence should be addressed to Timothy S. Balmer, Trussell Laboratory, Oregon Hearing Research Center, Oregon Health and Science University, Portland, OR 97239. E-mail: balmer@ohsu.edu.

DOI:http://dx.doi.org/10.1523/ENEURO.0112-16.2016

Copyright (C) 2016 Balmer

This is an open-access article distributed under the terms of the Creative Commons Attribution 4.0 International, which permits unrestricted use, distribution and reproduction in any medium provided that the original work is properly attributed.
Härtig et al., 2001; Blosa et al., 2013), which contains some of the fastest and most precisely firing neurons. The auditory brainstem circuit transmits signals from the periphery with precision and speed in order to compare the timing and loudness of sounds between the two ears (Trussell, 1997, 1999; Oertel, 1999; Ashida and Carr, 2011). Differences in spike timing are used to compute the location of a sound in the environment of the animal. Principal neurons in the medial nucleus of the trapezoid body (MNTB) can follow extremely fast afferent stimulation $(>1000 \mathrm{~Hz}$ ) with incredible accuracy (Kim et al., 2013). The development of reliable fast spiking in MNTB occurs after postnatal day 14 (P14; Taschenberger and von Gersdorff, 2000), which correlates with the formation of PNNs around the principal neurons (Myers et al., 2012). The increase in spike reliability has been attributed to changes to the anatomy of the large axosomatic calyx of Held synapse, which is the main input to MNTB principal neurons (Taschenberger et al., 2002). PNN development may provide additional optimization for fast-spiking activity.

The role of PNNs in the physiology of fast-spiking neurons was tested by recording from mature mouse MNTB principal neurons and parvalbumin-expressing cortical interneurons in acute brain slices. Chondroitinase-treated cells had a marked decrease in evoked activity and a consistent delay relative to control-treated cells. The development of PNNs around somata of fast-spiking neurons may tune fast sensory transmission and inhibition in the brain.

\section{Materials and Methods}

\section{Slice preparation}

C57BL/6 mice of both sexes between P21 and P28 were used for MNTB recordings. CB6-Tg(Gad1-EGFP) G42Zjh/J (RRID:IMSR_JAX:007677; Chattopadhyaya et al., 2004) mice of both sexes >P70 were used for cortical neuron recordings. Mice were anesthetized with isoflurane and decapitated following the standards of humane care developed by the National Institutes of Health and the Society for Neuroscience, and procedures were approved by the Marine Biological Laboratory Institutional Animal Care and Use Committee. The brain was rapidly extracted into ice-cold high-sucrose artificial cerebrospinal fluid (ACSF) containing the following (in $\mathrm{mm}$ ): 230 sucrose, 25 glucose, $2.5 \mathrm{KCl}, 3 \mathrm{MgCl}_{2}, 0.1 \mathrm{CaCl}_{2}, 1.25$ $\mathrm{NaH}_{2} \mathrm{PO}_{4}, 25 \mathrm{NaHCO}_{3}, 0.4$ ascorbic acid, 3 myo-inositol, and 2 Na-pyruvate, $\mathrm{pH} 7.4$, saturated with $95 \% \mathrm{O}_{2}$ and $5 \% \mathrm{CO}_{2}$ (Huang and Trussell, 2011). Coronal sections 200 $\mu \mathrm{m}$ thick for MNTB and 300-400 $\mu \mathrm{m}$ thick for cortex were prepared using a vibratome (VT1200S, Leica). Immediately after cutting, slices were incubated in $35^{\circ} \mathrm{C}$ recording ACSF containing either chondroitinase $A B C$ (ChABC) or penicillinase (P-ase) for $1 \mathrm{~h}$, followed by storage at 
room temperature. Recording ACSF contained the following (in mM): $125 \mathrm{NaCl}, 25$ glucose, $2.5 \mathrm{KCl}, 1 \mathrm{MgCl}_{2}, 2 \mathrm{CaCl}_{2}$, $1.25 \mathrm{NaH}_{2} \mathrm{PO}_{4}, 25 \mathrm{NaHCO}_{3}, 0.4$ ascorbic acid, 3 myoinositol, $2 \mathrm{Na}$-pyruvate, and $\sim 305 \mathrm{mOsm}, \mathrm{pH} 7.4$, saturated with $95 \% \mathrm{O}_{2}$ and $5 \% \mathrm{CO}_{2}$ (Huang and Trussell, 2011).

\section{Enzymatic degradation of PNNs}

Immediately after slicing, brain slices were incubated in $0.2 \mathrm{U} / \mathrm{ml} \mathrm{ChABC}$ (catalog \#2905, Sigma-Aldrich) or control enzyme P-ase (catalog \#P0389, Sigma-Aldrich) in recording ACSF for $1 \mathrm{~h}$ at $35^{\circ} \mathrm{C}$ in a small slice chamber (BSK2, Scientific Systems Design). ChABC is a well characterized enzyme that degrades PNNs by removing glycosaminoglycan (GAG) side chains from chondroitin sulfate proteoglycans, reduces PNN labeling in acute slices (Bukalo et al., 2001), and reduces cell surface charge (Morawski et al., 2015).

\section{Whole-cell current-clamp recordings}

Slices were transferred to a submerged recording chamber and superfused with ACSF heated to $33-35^{\circ} \mathrm{C}$ at 3-4 $\mathrm{ml} / \mathrm{min}$. Slices were viewed using infrared differential interference contrast (IR-DIC) and a $63 \times$ water-immersion objective (AxioExaminer, Zeiss) and camera (Flash4-LT, Hamamatsu). Pipettes were pulled from thick-walled borosilicate glass capillaries $(1.5 \mathrm{~mm}$ outside diameter; WPI) to a tip resistance of 2-4 M $\Omega$. The internal pipette solution contained the following (in $\mathrm{mM}$ ): $113 \mathrm{~K}$-gluconate, 4.8 $\mathrm{MgCl}_{2}$, 4 ATP, 0.5 Tris-GTP, 14 Tris-phosphocreatine, 0.1 EGTA, and 10 HEPES, pH 7.25 with $\mathrm{KOH}, \sim 290$ mOsm. Reported voltages are corrected for a $-10 \mathrm{mV}$ liquid junction potential. Whole-cell recordings were amplified and low-pass filtered $(6 \mathrm{kHz}$; Multiclamp 700B, Molecular Devices) and digitized using pClamp software (50-100 kHz; Digidata 1550, Molecular Devices). MNTB neurons were verified by their physiological properties (low input resistance, transient firing pattern, and outward rectification) and in some cases were filled with a fluorophore (20 $\mu \mathrm{M}$ Alexa Fluor 594; catalog \#A10438, Life Technologies) and recovered post hoc. Parvalbuminexpressing $(\mathrm{PV}+)$ cortical neurons were identified by EGFP expression and fast-spiking activity during positive current steps. Bias current was not used to maintain resting membrane potential in any cells.

\section{White noise current stimulation}

The Gaussian noise current stimulus was synthesized in Matlab (MathWorks) by passing Gaussian white noise through an exponential filter with a correlation time of 0.5 ms (2 kHz; Bryant and Segundo, 1976; Slee et al., 2005; Mease et al., 2013). This 500 ms frozen noise stimulus was multiplied to create four noise levels [measured as the SD of the noise $(0,200,400$, and 600 pA SD) and superimposed on seven current steps $(0-600 \mathrm{pA})]$. Each cell was stimulated with all 28 levels of noise and a DC step five times in a pseudorandom order with $750 \mathrm{~ms}$ interstimulus intervals.

\section{Immunohistochemistry and microscopy}

After recording, slices were fixed for $2 \mathrm{~h}$ overnight in $4 \%$ paraformaldehyde in $0.1 \mathrm{~m}$ phosphate buffer and rinsed in
$0.1 \mathrm{~m}$ PBS. Slices were incubated in biotinylated Wisteria floribunda agglutinin (WFA; $20 \mu \mathrm{g} / \mathrm{ml}$; catalog \#L1516, Sigma-Aldrich) for $1 \mathrm{~h}$. After rinsing in PBS, slices were incubated in streptavidin-Alexa Fluor $488(20 \mu \mathrm{g} / \mathrm{ml}$; catalog \#S11223, Life Technologies; RRID:AB_2336881) for $1 \mathrm{~h}$. Slices were mounted to microscope slides and coverslipped with $90 \%$ glycerol and $10 \%$ PBS, pH 9.0. Slices were imaged with an epifluorescence microscope (Imager.Z2 with Colibri LED System, Zeiss). For quantification of PNN brightness a $20 \times / 0.8$ numerical aperture objective (Plan Apochromat, Zeiss) was used, and consistent LED brightness (25\%) and exposure time (150 ms) were maintained across all sections imaged. All immunohistochemistry was performed in parallel with the same reagents, and imaging was performed blinded to the treatment condition in the same imaging session. PNN labeling was quantified by measuring pixel intensities within an outlined area circumscribing MNTB (ImageJ; RRID:SCR_003070; Schneider et al., 2012).

\section{Data analysis}

Clampfit (pClamp, Molecular Devices) was used to measure spike shape properties. Matlab was used for the analysis of pulse trains, voltage threshold, and white noise stimulation. Statistical analyses were performed in Matlab, Sigmaplot (SyStat), and Excel (Microsoft).

\section{Spike shape analysis}

Depolarizations that crossed $-30 \mathrm{mV}$ and had the shape of an action potential were considered to be spikes. Spike amplitudes were measured as the peak membrane potential relative to the preceding resting membrane potential. Spike widths were measured at half the spike amplitude. Rising slopes were based on $30-$ $90 \%$ peak measurements, and falling slopes were based on $10-90 \%$ peak measurements. Input resistance was calculated as the slope of the linear portion of the currentvoltage (I-V) curve ( -150 to $0 \mathrm{pA}, 500 \mathrm{~ms}$ steps). Inward rectification was estimated as the difference between the transient hyperpolarization and the steady-state membrane potential during a $-500 \mathrm{pA}$ step. Outward rectification was estimated as the difference between the steady-state response during a $450 \mathrm{pA}$ step and an extrapolation of the linear portion of the $I-V$ curve to $450 \mathrm{pA}$. This measure indicates the difference between the measured membrane potential during a $450 \mathrm{pA}$ step and the predicted membrane potential, given a linear increase in membrane potential. Afterhyperpolarization (AHP) was measured as the difference between the resting membrane potential preceding the spike and the minimum membrane potential after the spike (or train of spikes).

\section{Spike threshold}

Spike voltage thresholds were calculated using a phase-plane analysis, plotting the membrane potential versus the $\mathrm{dV} / \mathrm{dt}$ and measuring the voltage where $\mathrm{dV} / \mathrm{dt}$ crossed an empirically defined level of $40 \mathrm{mV} / \mathrm{ms}$. Other methods including $30-100 \mathrm{mV} / \mathrm{ms}, 2-3$ SDs above the mean, and the peak of the first or second time derivative of voltage were also used, and the results were similar. 

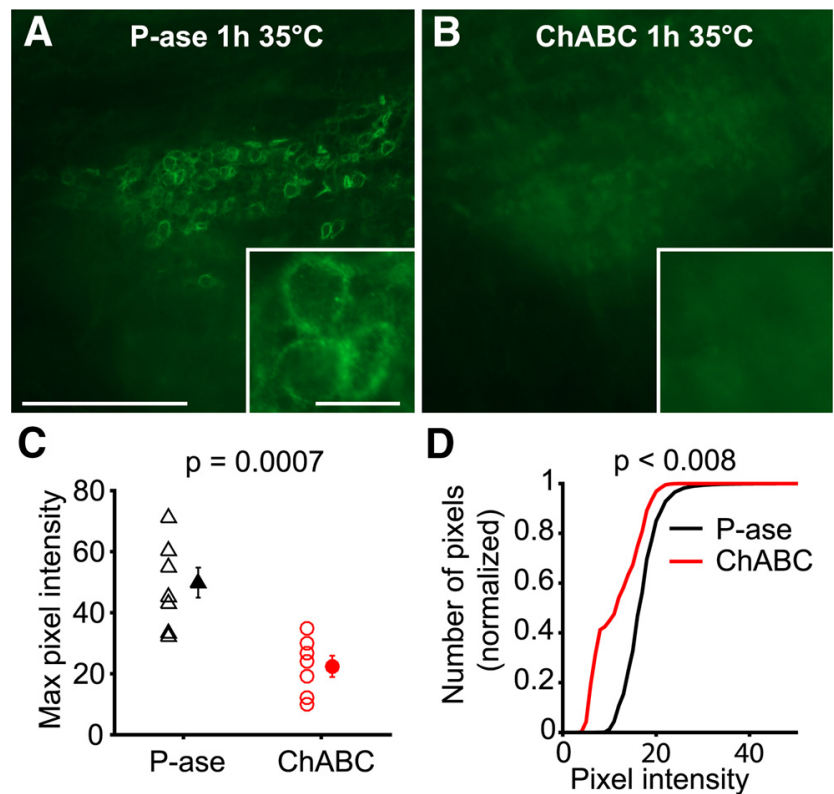

Figure 1. ChABC effectively degrades $P N N s$ in acute brain slices during slice recovery. A, WFA-labeled PNNs are visible surrounding MNTB neurons after $P$-ase treatment (negative control). Scale bars: $200 \mu \mathrm{m}$; inset, $20 \mu \mathrm{m}$. $\boldsymbol{B}$, ChABC-treated slices had reduced PNN labeling. $\boldsymbol{C}$, Maximum pixel intensities in MNTB were reduced by ChABC ( $t$ test, $p=0.0007$ ). Error bars are the mean and SEM. $\boldsymbol{D}$, Cumulative plot of pixel intensities shows that ChABC-treated MNTB regions have reduced brightness (twosample Kolmogorov-Smirnov, $p<0.008$ ). Slices were labeled in parallel with the same reagents and imaged with the same microscope settings.

\section{Relative spike delay}

To quantify the difference between spike times in ChABC-treated cells vs P-ase-treated cells, a peristimulus time histogram (PSTH) was made by combining the first trial of each cell. Calculations were triggered every time at least $25 \%$ of the P-ase-treated cells spiked within a $0.25 \mathrm{~ms}$ bin. For each of these "spike events," the mean time of spike peaks that occurred in the ChABC or P-asetreated group within $1 \mathrm{~ms}$ were compared. A positive delay represents $\mathrm{P}$-ase spikes leading the ChABC spikes.

\section{Results}

\section{ChABC treatment effectively degraded PNNs in acute brain slices}

To test how PNNs affect the physiology of the cells that they surround, PNNs were either degraded or left intact in acute mouse brain slices. Slices were incubated in either ChABC, an enzyme that digests the GAG chains of the $\mathrm{PNN}$, or P-ase as a negative control treatment. The slices were maintained in these solutions for $1 \mathrm{~h}$ at $35^{\circ} \mathrm{C}$ with constant $95 \% \mathrm{O}_{2}$ and $5 \% \mathrm{CO}_{2}$ saturation. In P-asetreated control slices, there were many PNNs labeled in MNTB by the lectin WFA, which labels GAG chains (Fig. $1 A)$. PNN labeling was greatly reduced by the $1 \mathrm{~h}$ ChABC treatment, although it was not completely abolished (Fig. $1 B$ ). The maximum pixel intensities within MNTB were significantly reduced by ChABC treatment $(t$ test, $p=$
$0.0007, N=15$ slices; Fig. $1 C$ ). The distribution of pixel intensities within MNTB was negatively shifted by ChABC treatment (two-sample Kolmogorov-Smirnov test, $p<$ $0.008, N=15$ slices; Fig. $1 D$ ).

\section{PNN degradation did not affect passive properties,} spike shape, or spike failures

Whole-cell current clamp recordings were made from MNTB-containing slices that were treated with ChABC or $\mathrm{P}$-ase. Slices treated with either enzyme were indistinguishable in appearance from untreated slices under IRDIC imaging. The presence of PNNs did not affect the ability to make low-resistance whole-cell recordings. There was no effect of treatment condition on resting membrane potential, input resistance, or inward or outward rectification ( $t$ tests, $p>0.05$; Fig. $2 A-C$; Table 1 ), suggesting that $\mathrm{Ch} A B C$ treatment did not alter the viability of the neurons. Moreover, any differences observed in spiking activity are unlikely to be caused by changes in passive membrane properties.

To investigate the effect of PNNs on spike shape, a single action potential was evoked by a $450 \mathrm{pA}, 500 \mathrm{~ms}$ step or a $4 \mathrm{nA}, 0.1 \mathrm{~ms}$ pulse, which lead to different spike shapes (Johnston et al., 2009). Properties of action potential shape and timing were not significantly different between ChABC- and P-ase-treated groups for either protocol ( $t$ tests, $p>0.05$; Table 2; Fig. 3). Trains of action potentials were elicited by a series of $504 \mathrm{nA}, 0.1 \mathrm{~ms}$ pulses at rates of $100,300,500,800$, and $1000 \mathrm{~Hz}$. All cells spiked in response to every current pulse at 100 , 300 , and $500 \mathrm{~Hz}$. Some cells failed at 800 and $1000 \mathrm{~Hz}$, but there were no statistically significant differences between the treatment groups ( $\chi^{2}$ tests, $\left.p>0.05\right)$. Example traces for $1000 \mathrm{~Hz}$ stimulation are shown in Figure $2 D$. Spike properties including the measurements that were used for single spikes in Figure 3 were quantified across the 50 spikes in the train. None of these properties were significantly affected by ChABC treatment at any of the tested frequencies. The action potential amplitude tended to be $5-10 \mathrm{mV}$ shorter in the ChABC-treated cells, although this difference did not reach statistical significance. In addition, the afterhyperpolarization at the end of the train (of 50 successful spikes) and the interspike potential were not different between treatment groups at any stimulation frequency ( $t$ tests, $p>0.05$ ). Thus, PNNs were not necessary for MNTB neurons to spike at up to 1000 $\mathrm{Hz}$ in response to large square currents.

\section{ChABC treatment reduced the excitability of MNTB neurons}

To investigate whether PNNs have an effect on the spike output of MNTB neurons in response to fluctuating currents, cells were stimulated with currents that contained a range of amplitudes and frequencies (Bryant and Segundo, 1976; Slee et al., 2005; Street and Manis, 2007; Mease et al., 2013). A Gaussian distributed "white noise current" was synthesized and filtered such that it would contain frequencies up to $2 \mathrm{kHz}$ (see Materials and Methods). The same current was injected with varying gain (noise level), measured as the SD of the current (0-600 pA SD) and varying positive bias current (0-600 pA DC steps). 


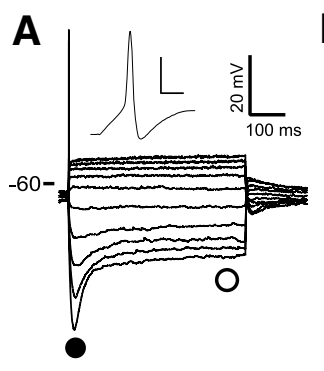

D
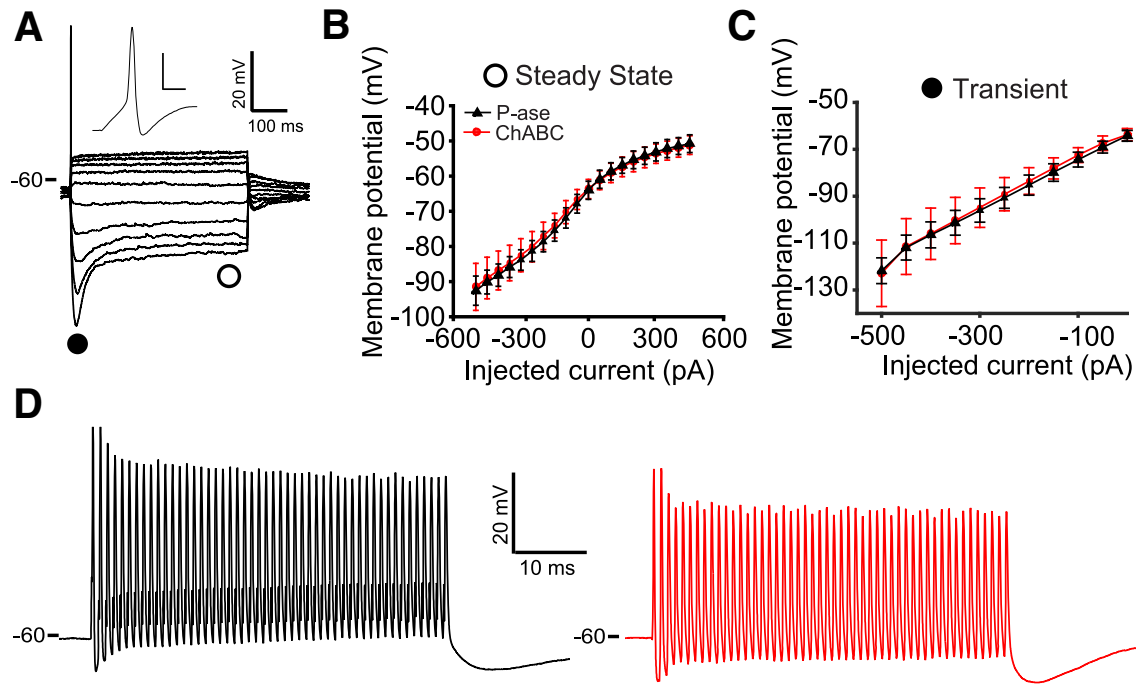

Figure 2. Passive membrane properties were not affected by ChABC treatment. $\boldsymbol{A}$, Response to current steps show that hyperpolarization activated transient, outward rectification and a single spike on depolarizing steps. Inset shows a spike with an extended time base. Inset calibration: $20 \mathrm{mV}, 1 \mathrm{~ms}$. $\boldsymbol{B}, \mathrm{ChABC}$ treatment did not affect the $I-V$ curve measured when the membrane reached steady state (as indicated by the open circle in $\boldsymbol{A}$ ), or $\boldsymbol{C}$, size of the hyperpolarizing transient, measured at the peak (filled circle in $\boldsymbol{A}$ ). Error bars are the mean and SEM. $\boldsymbol{D}$, Both P-ase-treated (left) and ChABC-treated (right) neurons were able to fire at $1000 \mathrm{~Hz}$ in response to a train of $4 \mathrm{nA}, 0.1 \mathrm{~ms}$ pulses.
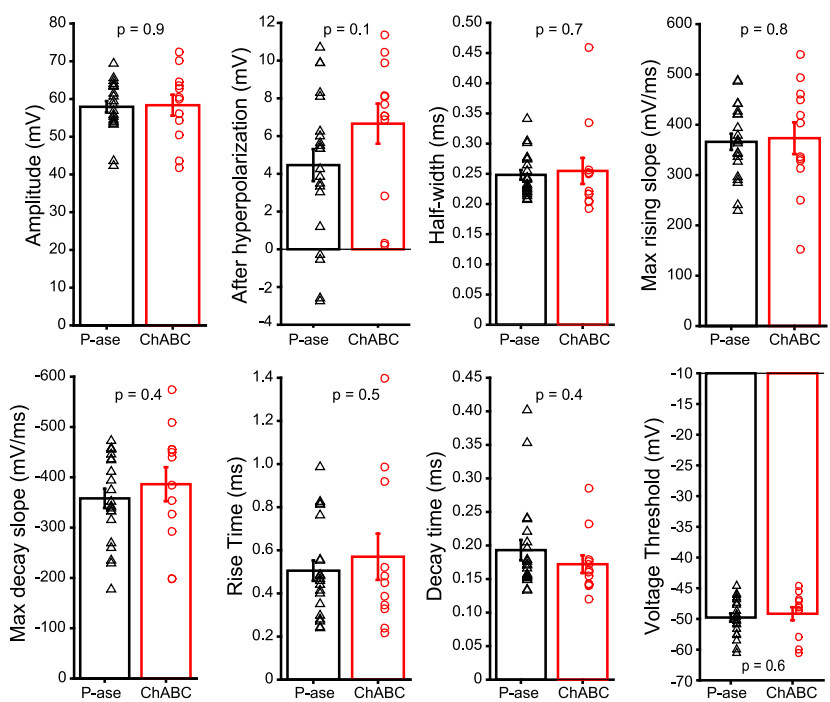

Figure 3. Spikes evoked by 450 pA, 500 ms current step were not affected by ChABC treatment. Data points are individual cells. Error bars are the mean and SEM.

Figure $4 A$ shows an example white noise current with 400 $\mathrm{pA}$ noise level superimposed on four of the seven DC steps, and with an expanded time base in Figure $4 B$. All cells were stimulated with the same synthesized currents.

ChABC-treated cells fired markedly less in response to white noise current stimulation. Over all trials and levels of the white noise currents, the ChABC-treated cells fired on average $67.6 \%$ the number of spikes that P-ase-treated cells fired (mean \pm SD; P-ase cells: 10,031 $\pm 2775, n=$ 11; ChABC: $6783 \pm 3108, n=9 ;$ t test, $p=0.024$ ). Figure $4 A$ shows an example trace from a P-ase-treated (black) and a ChABC-treated neuron (red) at the 400 pA SD noise level superimposed on four DC steps. This approach produced high-quality frequency-intensity $(f-l)$ curves for these cells, which are not possible with DC steps alone due to their transient firing behavior (Fig. 4C). ChABCtreated cells spiked significantly less at noise levels of 400 and $600 \mathrm{pA}$ compared with P-ase-treated cells [two-way repeated-measures (RM) ANOVAs, interaction $p<0.05$; Fig. $4 C]$. The maximum slope of the $f-l$ curves, which indicates the gain of firing as the DC steps increase, was lower in ChABC-treated cells at all noise levels (two-way RM ANOVA, $p=0.03$; Fig. $4 D$ ). The distribution of the instantaneous spike rates was shifted to lower frequencies in ChABC-treated cells, but the overall shape of the distribution was similar to P-ase-treated cells (Fig. 4E). This suggests that the change in firing rate was not due to a change in spiking pattern. For example, if the ChABCtreated cells started firing in bursts with large interburst intervals, the distribution would show an increase in high instantaneous firing rates and a decrease in low rates. In sum, ChABC-treated cells were less excitable than P-asetreated cells.

Importantly, these differences in firing rate were not due to differences in membrane potential depolarization during the steps, which was measured by filtering out the spikes (two-way RM ANOVA, $p>0.05$; Fig. 5A,B). This agrees with the finding that the input resistance of ChABC-treated cells was not different than P-ase-treated cells (Table 1). The resting membrane potential measured between the steps was also not different between groups (two-way RM ANOVA, $p>0.05$; Fig. 5C). Thus, the reduced excitability of MNTB neurons treated with ChABC is not due to changes in passive membrane properties.

\section{Spike-triggered average shows ChABC-treated cells required more current to spike}

The currents that were injected immediately prior to each spike were averaged within each level of noise and DC step. Figure $6 A$ shows example spike-triggered averages (STAs) for a cell treated with P-ase (black) and for another cell treated with ChABC (red) across four DC steps. The peak of the STAs was significantly higher during the 200 , 400 , and 600 pA noise levels in the ChABC-treated cells (two-way RM ANOVAs, $p<0.05$; Fig. 6B). This indicates that the ChABC-treated cells required larger currents to 
A

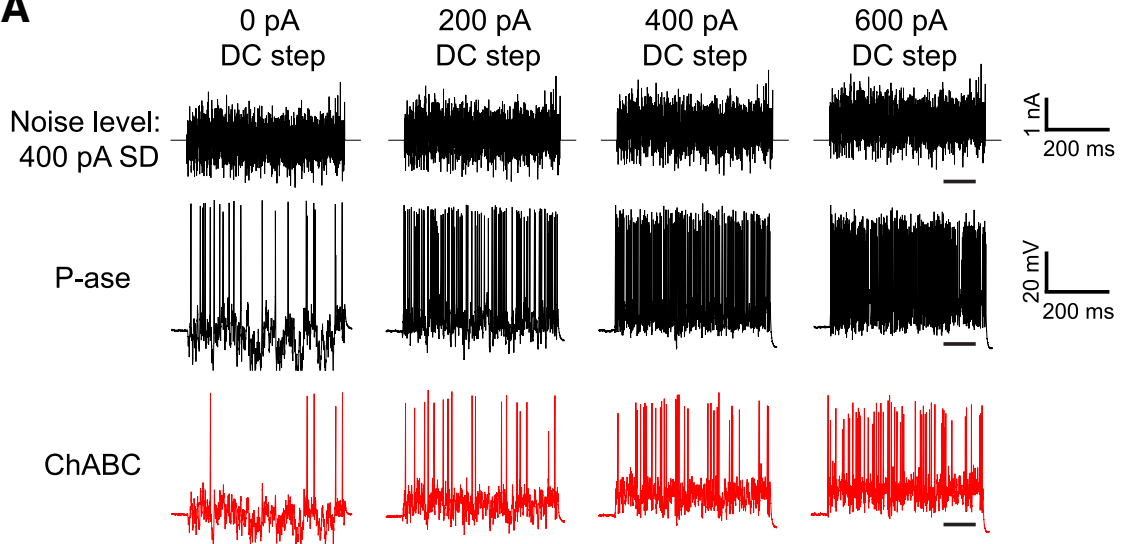

B

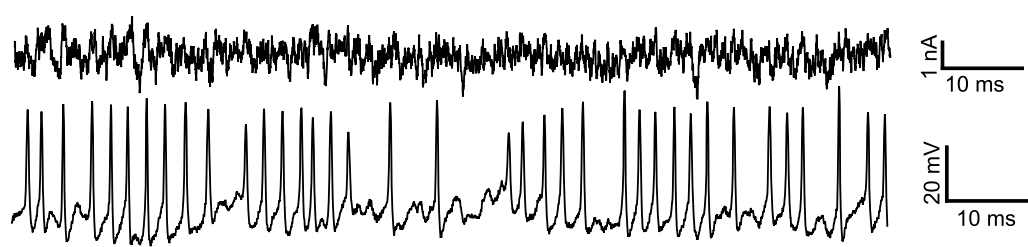

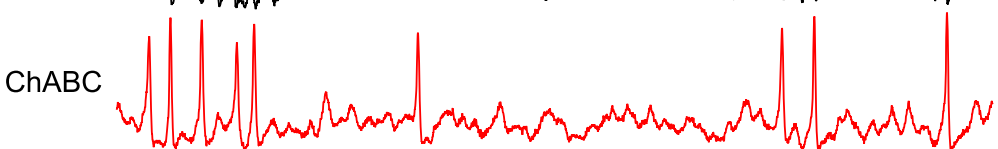

C
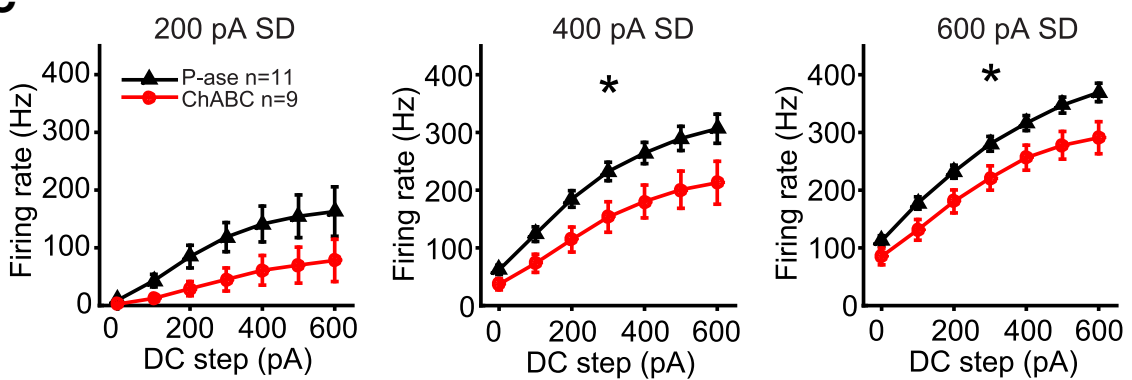

Figure 4. ChABC-treated MNTB neurons exhibited lower gain. $\boldsymbol{A}$, Example white noise currents with noise level of 400 pA SD at four levels of DC step (top), spiking response in a $\mathrm{P}$-asetreated cell (middle, black), and spiking response in a ChABC-treated cell (bottom, red). $\boldsymbol{B}$, Expanded time base showing spiking responses from the traces in $\boldsymbol{A}$ at the time indicated by underlining in $\boldsymbol{A}$ in the $600 \mathrm{pA}$ DC step condition. $\boldsymbol{C}, f-I$ curves indicate significantly lower firing rates in ChABCtreated cells compared with $\mathrm{P}$-asetreated cells (*two-way RM ANOVA, $p$ $<0.05)$. $\boldsymbol{D}$, Maximum gain calculated from the $f-l$ curves was significantly lower in ChABC-treated cells, indicating reduced excitability (*two-way RM ANOVA, $p<0.05)$. $E$, The distribution of instantaneous firing rates was shifted to lower frequencies and did not indicate a change in spiking pattern.

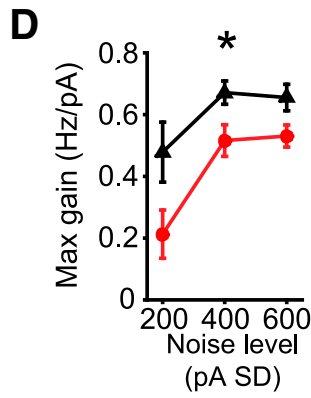

E

spike. The slopes of the STA currents were not different between groups, nor were their preceding troughs.

\section{Spike threshold was more depolarized in ChABC- treated cells}

ChABC treatment did not affect passive properties that might explain the observed reduction in spiking, such as input resistance or resting membrane potential (Table 1, Fig. 5). A change in the voltage threshold for spikes could underlie the change in spike rate. Spike thresholds were calculated by making a phase-plane plot of the membrane potential and measuring the voltage at which the $\mathrm{dV} / \mathrm{dt}$ crossed an empirically defined level of $40 \mathrm{mV} / \mathrm{ms}$ (Fig. 7A; see Materials and Methods). The variance of the voltage thresholds during each noise current injection was high, but did not differ between treatment groups. Because the firing rate can affect voltage thresholds (Henze and Buzsáki, 2001), comparisons between treatment groups were made across DC steps that evoked comparable firing rates. Voltage thresholds of ChABC-treated cells were significantly depolarized at firing rates of $0-50,50-100$, and $100-150 \mathrm{~Hz}$ during the $400 \mathrm{pA}$ SD noise level, and at 
A

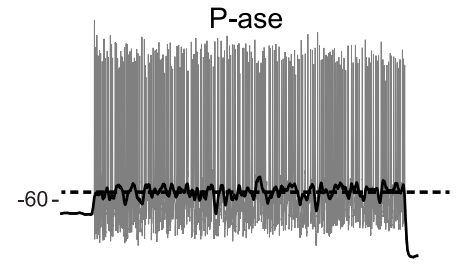

B
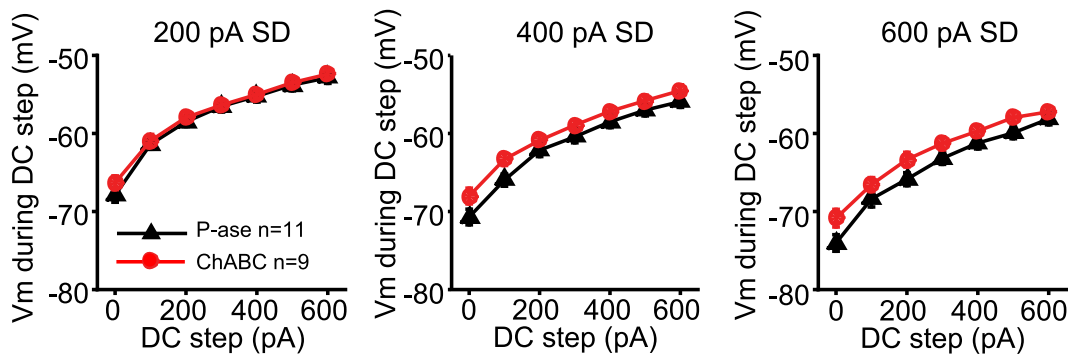

C
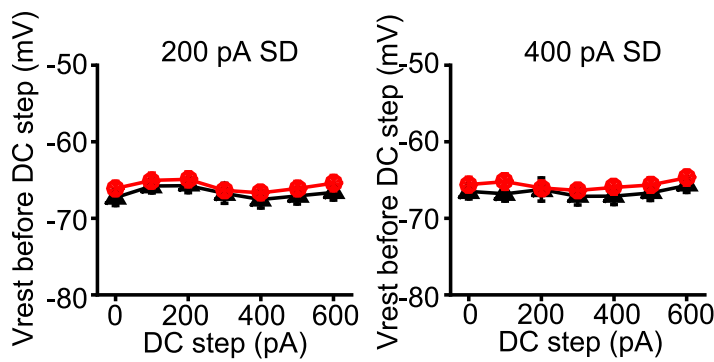

Figure 5. Input resistance and resting membrane potential were not different between treatment groups. $\boldsymbol{A}$, Traces were low-pass filtered to calculate the membrane potential during white noise current stimulation. Thick dark line is the filtered trace plotted over the original trace. Dashed horizontal line indicates the mean membrane potential $(\mathrm{Vm})$ during the current step. These values were used to compare the membrane potential during DC steps shown in $B$. Examples traces are at the $400 \mathrm{pA}$ noise level and 600 pA DC step. $\boldsymbol{B}$, There were no significant differences between treatment groups at any noise level (two-way RM ANOVA, $p>0.05$ ). C, Resting membrane potential (Vrest) was calculated as the membrane potential before the current injection. There were no differences between treatment groups at any noise level (two-way RM ANOVA, $p>0.05$ ).
150-200 Hz during the $600 \mathrm{pA}$ noise level, compared with P-ase-treated cells ( $t$ tests, $p<0.05$; Fig. $7 B$ ).

Spike amplitude of ChABC-treated cells were also reduced at firing rates of $0-50 \mathrm{~Hz}$ during the $200 \mathrm{pA} \mathrm{SD}$ noise level, $50-100$ and $100-150 \mathrm{~Hz}$ during the $400 \mathrm{pA}$ noise level, and $150-200 \mathrm{~Hz}$ during the 600 pA SD noise level, compared with $\mathrm{P}$-ase-treated cells ( $t$ tests, $p<0.05$; Fig. 7C). The speed of the upstroke of the spikes evoked by white noise stimulation was slower in the ChABCtreated cells (Fig. 7D). The acceleration of the membrane potential was significantly slower in ChABC-treated cells at firing rates of $50-100 \mathrm{~Hz}$ during the $400 \mathrm{pA}$ SD noise level, and $150-200$ and $200-250 \mathrm{~Hz}$ during the $600 \mathrm{pA}$ noise level ( $t$ tests, $p<0.05)$. These observations are consistent with a change in a $\mathrm{Na}^{+}$conductance after PNN degradation.

Table 1: MNTB neuron passive properties were not different between treatment groups

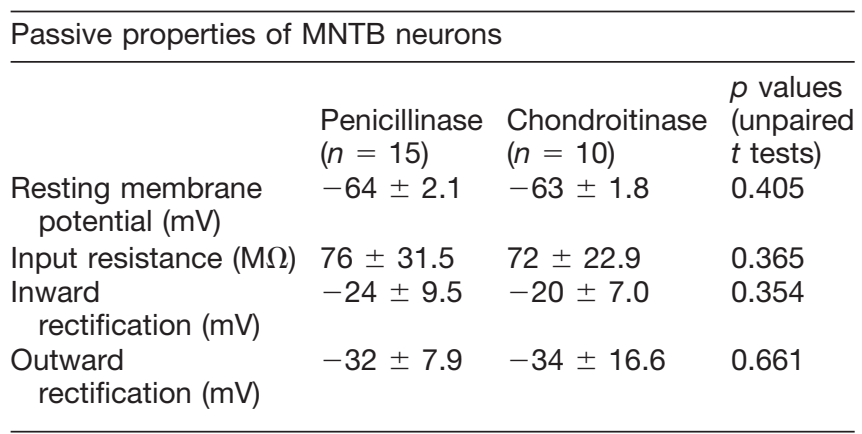

Values are reported as the mean $\pm S D$, unless otherwise indicated.

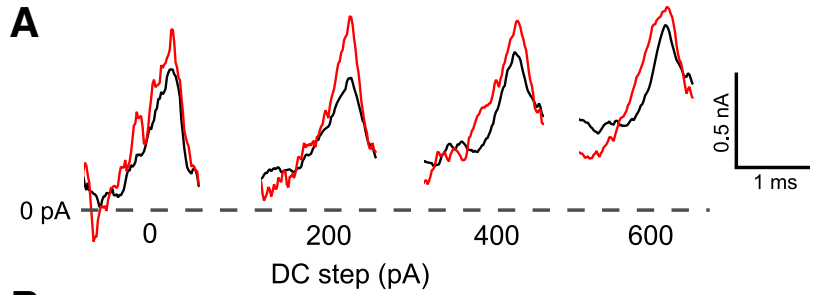

B
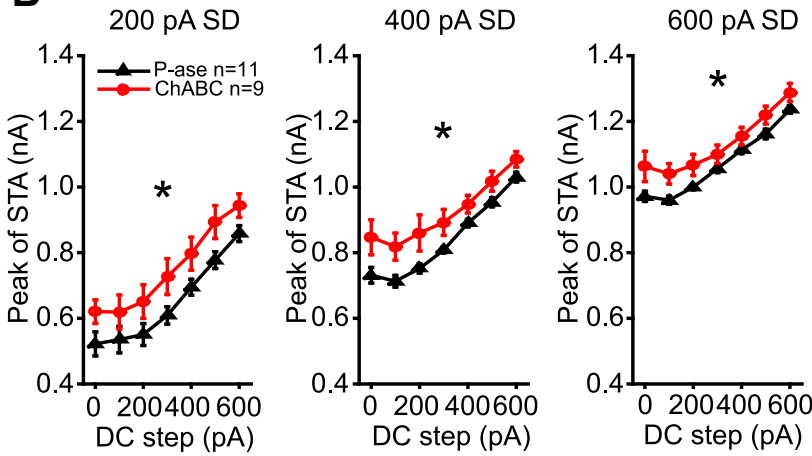

Figure 6. STAs of injected currents reveal higher current threshold in ChABC-treated MNTB neurons. Injected currents that triggered spikes were aligned and averaged. $\boldsymbol{A}$, Overlaid examples of P-ase-treated (black) and ChABC-treated (red) cells at the $400 \mathrm{pA}$ SD noise level superimposed on four DC current steps. The peaks of the action potentials were aligned with the rightmost point of each STA. Note that in these examples the peak of the STA is higher in the ChABC-treated cell than in the P-ase-treated cell. $\boldsymbol{B}$, The average STA peak across cells was significantly higher among the ChABC-treated cells than the P-ase-treated cells (*two-way RM ANOVA, $p<0.05$ ). Error bars are the mean and SEM. 


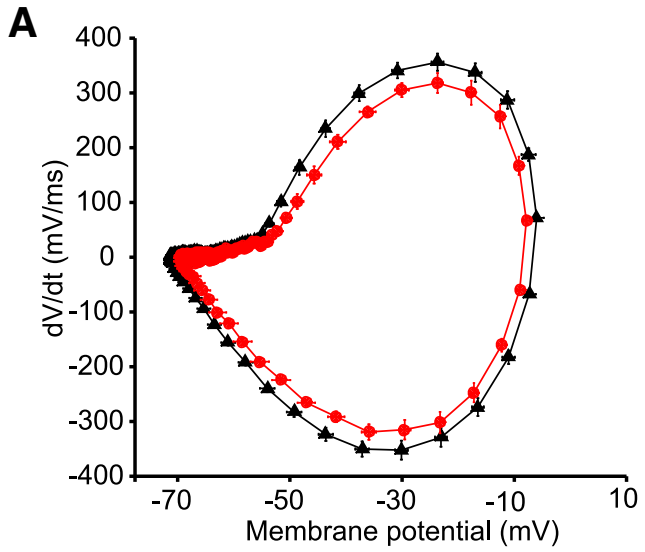

B
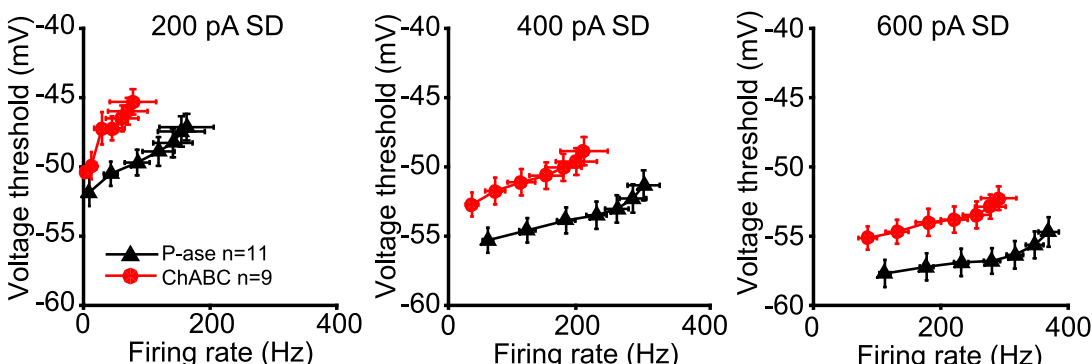

C
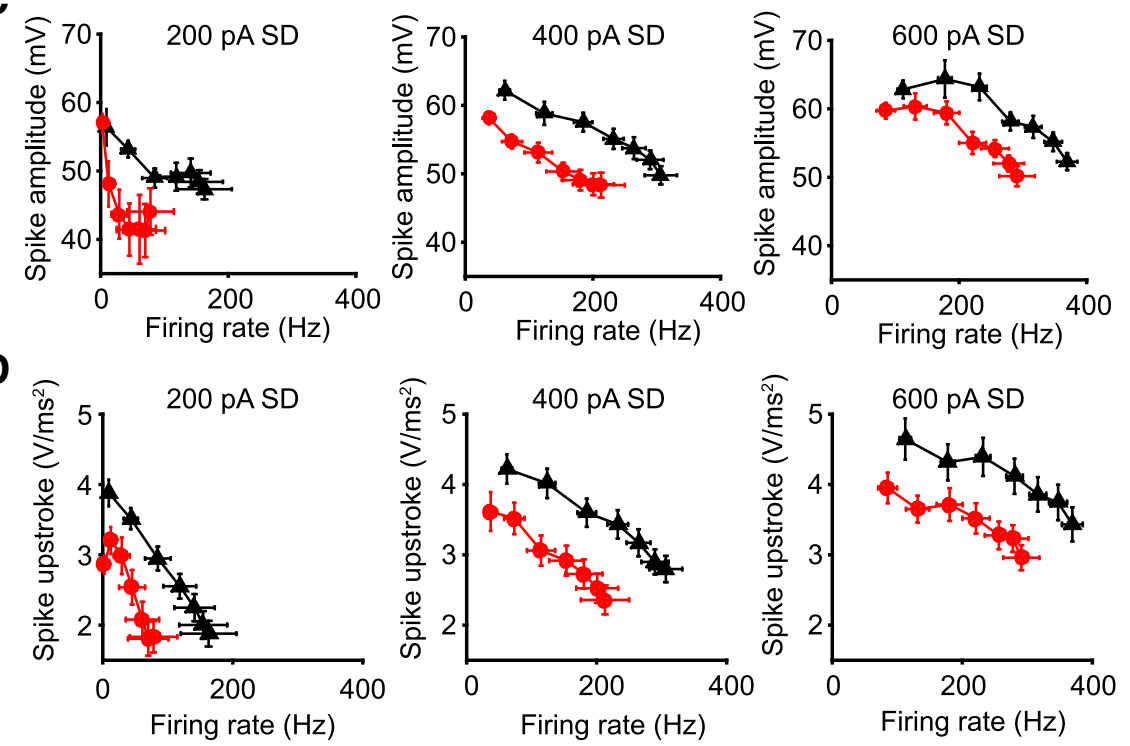

Figure 7. Voltage threshold and spike shape during fast spiking. $\boldsymbol{A}$, Phase plane plots of white noise evoked spikes during 400 pA SD noise level without a DC step averaged across ChABC-treated (red) and P-ase-treated (black) cells. The membrane potential where the $\mathrm{dV} / \mathrm{dt}$ begins to increase is more depolarized in ChABC-treated cells, indicating a more depolarized voltage threshold. Also note that the upstroke of the spike is slower (lower peak dV/dt) and reaches a lower membrane potential. $\boldsymbol{B}$, Voltage thresholds were significantly depolarized in ChABC-treated cells compared with P-ase-treated cells (see Results). Each marker indicates a DC step (from 0 to $600 \mathrm{pA})$ plotted at the average evoked firing rate and the average voltage threshold during the step. $\boldsymbol{C}$, Spike amplitude was significantly smaller in ChABC-treated cells. $\boldsymbol{D}$, The acceleration of the membrane potential was significantly lower in ChABC-treated cells. Error bars are the mean and SEM.
Spikes in ChABC-treated cells had a delayed onset If spike threshold was depolarized in ChABC-treated cells and passive membrane properties were not affected, then they should fire later in response to the identical sample of white noise current, compared with $\mathrm{P}$-ase-treated cells. Indeed, when spike trains evoked by the same white noise current were overlaid, it became apparent that the ChABC-treated cells not only did not fire each time the control cells did, but when they fired the spikes occurred later. Figure $8 A$ shows overlaid traces of every $\mathrm{P}$-asetreated (11 cells, black) and ChABC-treaded cell (9 cells, red). The mean spike times of the spikes that occurred within a $1 \mathrm{~ms}$ time window are indicated as vertical lines above the traces. Overall, $86 \%$ of these spike events were later in the ChABC-treated group than the P-ase-treated group, with an average relative delay of $\sim 70 \mu$ s (Fig. $8 B, C)$. There was no difference in the jitter of the spikes between groups.

\section{Cortical inhibitory interneurons were similarly affected by ChABC}

To test the generality of these results, cortical fast-spiking interneurons of >P70 mice were recorded. Older mice were used for these recordings than MNTB, because PNNs develop much later in the cortex than in the brainstem (Pizzorusso et al., 2002). GFP-expressing cells in the CB6-Tg(Gad1-EGFP)G42Zjh/J mouse line are presumed to be PV+ inhibitory interneurons (Chattopadhyaya et al., 2004). 

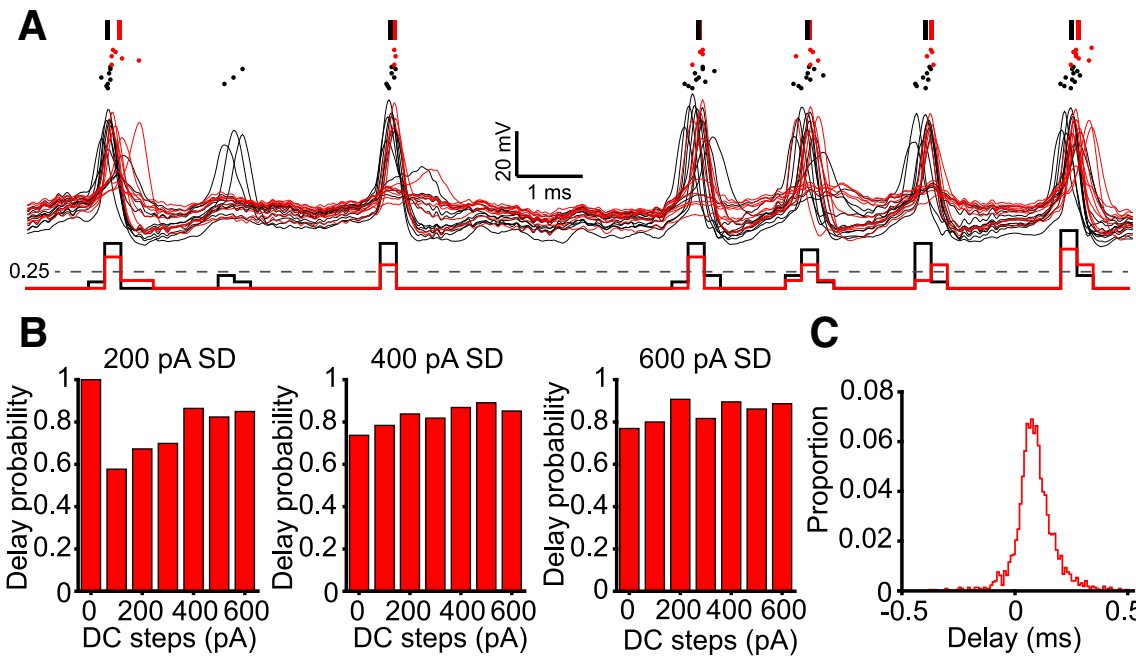

C

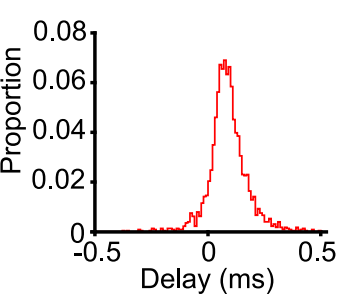

Figure 8. ChABC-treated cells consistently fired later than $\mathrm{P}$-ase-treated cells. $\boldsymbol{A}$, Each overlaid trace is from a different P-ase-treated (black) or ChABC-treated (red) cell. A dot raster is plotted above the spike trains, with each row indicating a different cell. The PSTH below indicates how spike events were identified. When a $0.25 \mathrm{~ms}$ bin reached a threshold where $\geq 25 \%$ of P-ase-treated cells fired, a mean spike time was calculated for spikes occurring within $1 \mathrm{~ms}$ centered on the bin. The vertical lines above indicate the mean spike time of the spikes within each 1 ms spike event. $\boldsymbol{B}$, The probability of the ChABC-treated cells to fire later than the $\mathrm{P}$-ase-treated cells during these spike events was high (>50\%) across all levels of gain and DC steps. $\boldsymbol{C}$, The distribution of the delays of spike events is shifted to the right, indicating that spikes usually occurred later in ChABC-treated cells than P-asetreated cells.
GFP-expressing cells in layers $4-6$ of somatosensory cortical slices were patched, and their fast-spiking phenotype was verified by injecting positive DC current steps without noise. In some cases, GFP ${ }^{+}$cells were filled with a fluorophore and labeled with WFA to verify that they had PNNs in the P-ase-treated group, and had attenuated PNNs in the ChABC-treated group (Fig. 9A). The resting membrane potential was not different between treatment groups (mean $\pm \mathrm{SD}$; P-ase: $-76 \pm 4.5 \mathrm{mV}, n=5$; ChABC: $-80 \pm 5.7 \mathrm{mV}, n=7$; $t$ test, $p=0.257$ ), nor was input resistance (P-ase: $82 \pm 33.1 \mathrm{M} \Omega, n=5$; ChABC 73 $\pm 20.3 \mathrm{M} \Omega, n=7$; $t$ test, $p=0.558$ ).

The same white noise current that was used for MNTB neurons (Fig. 4) was injected into the fast-spiking cortical neurons. The ChABC-treated PV + neurons fired significantly less in response to the white noise currents than P-ase-treated cells (two-way RM ANOVAs, $p<0.05$; Fig. $9 B, C)$. ChABC-treated cells fired $64.1 \%$ of the number of spikes that $\mathrm{P}$-ase-treated cells fired in response to the white noise currents (mean \pm SD; P-ase-treated: $9074 \pm$
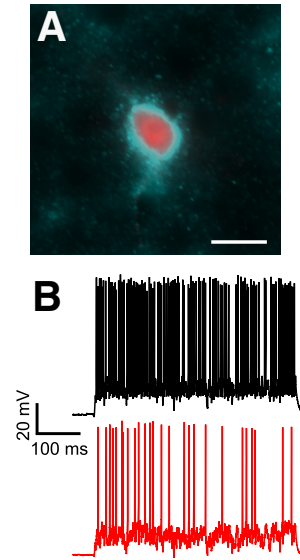
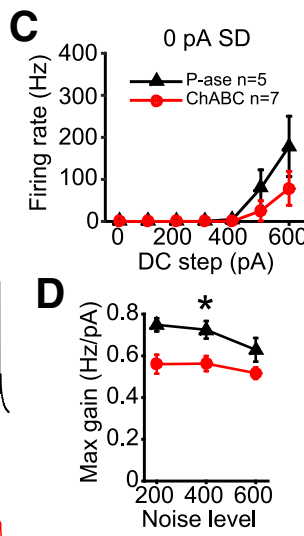

(pA SD)

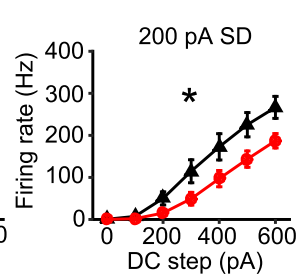

E

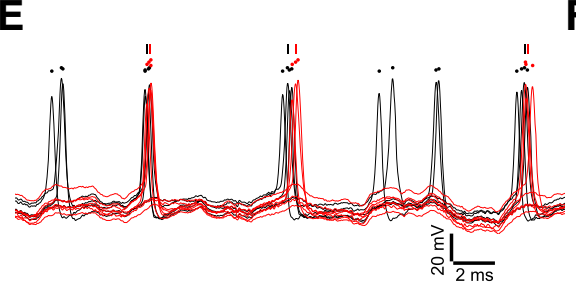

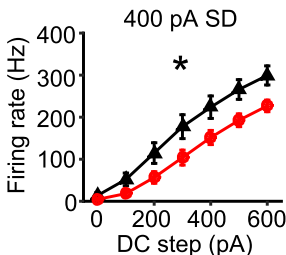

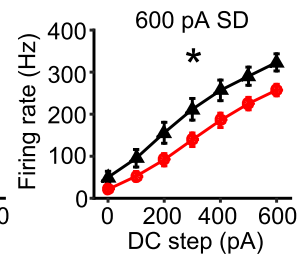

$\mathbf{F}$

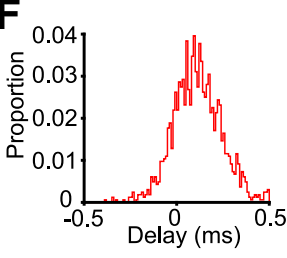

Figure 9. Parvalbumin-expressing fast-spiking cortical neurons were similarly affected by ChABC. A, Example of a PV + GFPexpressing cell that was filled with a fluorophore during recording (Alexa Fluor 594; red) and labeled post hoc with WFA (cyan). Scale bar, 10 um. B. Example traces showing responses to white noise current (400 pA SD, 300 pA DC step) in P-ase-treated cells (black) and ChABC-treated cells (red). $\boldsymbol{C}$, Fast-spiking cortical neurons treated with ChABC spiked significantly less than P-ase-treated cells in response to white noise currents (*two-way RM ANOVA, $p<0.05$ ). $\boldsymbol{D}$, Maximum gain calculated from the $f-l$ curves was significantly lower in ChABC-treated cells, indicating reduced excitability (*two-way RM ANOVA, $p<0.05$ ). $\boldsymbol{E}$, Overlaid traces from each P-ase-treated (black) and ChABC-treated (red) cell, illustrating that ChABC-treated cells fired spikes later than P-ase-treated cells. $\boldsymbol{F}$, Histogram showing rightward shift in delay, indicating that most spike events from ChABC-treated cells were delayed relative to P-ase-treated cells. 
2681, $n=7$; ChABC-treated: $5813 \pm 1845, n=5$; $t$ test, $p=0.031$ ). These neurons were less sensitive to the noise level than MNTB neurons, firing at similar rates at 200 , 400 , and $600 \mathrm{pA}$ noise SD levels. The gain of spiking was lower in ChABC-treated cells compared with $\mathrm{P}$-asetreated cells (two-way RM ANOVA, $p=0.03$; Fig. $9 D$ ). The spikes that occurred in ChABC-treated cells were delayed relative to those in P-ase-treated cells (Fig. 9E). A total of $65.5 \%$ of the spike events of ChABC-treated cells occurred after those of the P-ase-treated cells during the white noise current stimulation (Fig. 9F). Thus, both cortical PV + fast-spiking interneurons and MNTB principal neurons were affected in a similar way by PNN degradation. In both cases, the excitability of the cells was reduced. PNNs may be important for fast-spiking neurons in general to tune responses to input.

\section{Discussion}

PNNs have been correlated with the maturation of fastspiking neurons, but their role in spiking behavior has remained unclear (Härtig et al., 1999). In this study, enzymatic degradation of PNNs reduced spiking in two types of fast-spiking inhibitory neurons. MNTB principal neurons receive a single large synaptic input, are glycinergic, and project out of MNTB. Cortical PV+ neurons receive many synaptic inputs to their dendrites, are GABAergic, and are interneurons. PNN degradation had no observable effect on passive membrane properties, but reduced and delayed spiking in both cell types. The reason that ChABC-treated MNTB neurons fired less was not due to an inability to fire at high rates, because current pulses were able to drive spikes without failures. Instead, ChABC-treated cells had lower gain, firing less to fluctuating currents than control-treated cells. Thus, PNNs may enhance the gain of spike output in response to synaptic input during fast-spiking activity. Because PNNs typically surround inhibitory neurons, the development of PNNs may be a mechanism that enhances synaptic inhibition throughout the brain.

These results are consistent with a study that recorded extracellular spiking activity of MNTB principal cells in vivo in brevican knock-out mice, which have attenuated PNNs (Blosa et al., 2015). MNTB neurons in brevican knock-out mice fired at lower frequencies in response to sound than wild-type mice, and the sound pressure level threshold for evoking spikes was increased (Blosa et al., 2015). This change in spiking could not be attributed to an increase in transmission failures at the calyx of Held (Blosa et al., 2015). The present study suggests that the decrease in sound-evoked spiking in the brevican knockout mouse may be due to reduced excitability of the MNTB principal neurons.

In a recent study investigating the role of PNNs in synaptic plasticity, ChABC treatment did not affect the $f-I$ curves of CA2 hippocampal pyramidal neurons (Carstens et al., 2016). In contrast to the cells studied here, ChABC treatment significantly reduced the input resistance of these CA2 neurons (Carstens et al., 2016). This may have prevented the current pulses from causing the same level of membrane depolarization in the ChABC-treated cells and might explain why these neurons did not fire less after PNN degradation. Alternatively, PNNs may play different roles in neurons that do not fire at high frequencies. Whole-cell recordings have been made in dissociated cultures, which develop PNN-like structures (Miyata et al., 2005; Dityatev et al., 2007). Dissociated hippocampal interneuron cultures that were treated with $C h A B C$ had a reduced current threshold and reduced AHP compared with those of controls (Dityatev et al., 2007). These effects were not observed in this study, which is not suprising given that the PNNs likely develop differently in culture.

This is the first study to characterize frequency/intensity input/output functions of MNTB principal neurons. MNTB principal neurons fire a single spike in response to depolarizing current steps, which prevents the construction of meaningful $f-l$ curves. White noise stimulation was an effective and sensitive approach to reveal the excitabilty of these neurons. Moreover, in mice and other mammals with high-frequency hearing, MNTB neurons are unlikely to phase lock to physiologically relevant high-frequency sounds (Kopp-Scheinpflug et al., 2008). A fluctuating current that contains frequencies that are within the range of the hearing sensitivity of a mouse $(\sim 1-100 \mathrm{kHz})$ may be more similar to in vivo synaptic currents than traditional stimulation protocols consisting of current pulses delivered at lower frequencies $(<1 \mathrm{kHz})$.

This study focused on the effect of PNNs on nonsynaptic physiology because PNNs generally surround the soma and, in some cases, the axon initial segment and proximal dendrite. Other extracellular matrix molecules surround synapses, but generally these components are less dense than the PNN around the soma. The calyx of Held is a notable exception and is an attractive synapse to study the effect of PNNs, because PNN components are both inside and outside the cleft (Blosa et al., 2013). This study refuted the hypothesis that PNNs are necessary for fast spiking, at least in response to trains of $4 \mathrm{nA}$ current pulses. These current pulses were smaller than the initial excitatory postsynaptic current at the calyx of Held during a train, but were larger than currents at the end of a train, which are reduced by short-term synaptic depression. Spontaneous activity that occurs in vivo may reduce the synaptic currents further (Hermann et al., 2007). It is possible that PNNs reduce transmission failures due to depressed synaptic currents during ongoing physiological activity.

ChABC injection into the brain in vivo has been reported to enhance plasticity in adulthood in the visual cortex, perirhinal cortex, and amgdala (Pizzorusso et al., 2002, 2006; Gogolla et al., 2009; Romberg et al., 2013), but the mechanism by which this occurs remains quite unclear. The results reported here may shed light on how ChABC could enhance plasticity. For example, ocular dominance plasticity is reactivated by ChABC injections into the visual cortex (Pizzorusso et al., 2002, 2006) and by genetic manipulations of PNNs (Carulli et al., 2010). A variety of treatments that alter the excitatory/inhibitory balance of the visual cortex has been reported to control ocular dominance plasticity (Takesian and Hensch, 2013). Specific pharmacogenetic inhibition of $\mathrm{PV}+$ neurons in visual 
Table 2: MNTB neurons spike shape properties were not different between treatment groups

Spike shape properties of MNTB neurons

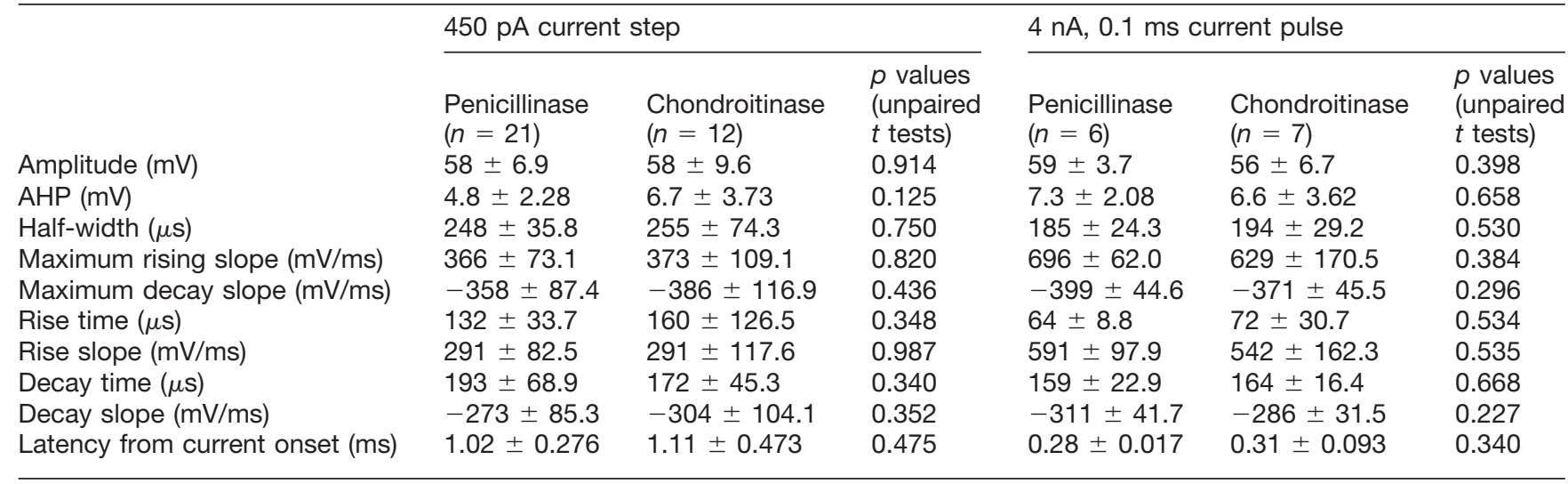

Values are reported as the mean $\pm S D$, unless otherwise indicated.

cortex extends the critical period for ocular dominace plasticity (Kuhlman et al., 2013). Reducing PV+ neuron activity may affect ocular dominance plasticity by shifting the ability for synapses to undergo synaptic plasticity (Kirkwood and Bear, 1994; Harauzov et al., 2010; Kuhlman et al., 2010). The present study suggests that ChABC injections into the visual cortex may reduce PV + cell spiking in vivo and thereby allow the synaptic plasticity that shapes binocular visual responses.

How might PNN degradation affect neuronal excitability? PNNs may prevent the diffusion of ion channels along the plasma membrane. AMPA receptors have been shown to diffuse more after the degradation of PNN-like structures that form around cultured hippocampal neurons (Frischknecht et al., 2009). Perhaps voltage-dependent $\mathrm{Na}^{+}$and $\mathrm{K}^{+}$channels that underlie spiking are maintained in clusters or prevented from being endocytosed by interactions with PNNs. Indeed, the voltage-dependent $\mathrm{Na}^{+}$Channel $\mathrm{Na}_{v} 1.2$ interacts with tenascin-R (Srinivasan et al., 1998), a major component of the PNN, although the function of this interaction has not been investigated.

It is possible that the voltage dependence of ion channels is affected by the PNN. PNNs are highly negatively charged (Morawski et al., 2015). Removal of this negative charge at the membrane could affect the local electric field sensed by the gating subunits of ion channels. This could have an effect that is similar to the extracellular application of high divalent cation solutions, which neutralize the membrane surface charge, shift channel gating to more depolarized membrane potentials, and reduce spiking (Frankenhaeuser and Hodgkin, 1957; Hille, 2001). The removal of PNNs could thus shift the activation of voltage-dependent ionic currents to higher voltages. In this case, PNNs may increase excitability by increasing the negative charge of the membrane and shift channel gating of one or more channel species to more hyperpolarized potentials.

Another way that neuronal excitability could be affected by $\mathrm{ChABC}$ is by reducing electrostatic interactions between the PNNs and cations. PNNs have been proposed to be a buffering system to maintain a stable microenvi- ronment of $\mathrm{Na}^{+}$and $\mathrm{K}^{+}$ions (Härtig et al., 1999). Although not further investigated here, this proposed buffering system may explain why ChABC treatment affected spike shape during fast spiking (evoked by the white noise currents; Fig 7), but not spikes evoked by current pulses (Table 2; Fig 3). Whether PNNs attract these $\mathrm{Na}^{+}$and $\mathrm{K}^{+}$ ions is unclear. However, ChABC increases the diffusion of calcium ions in cortical and hippocampal brain slices, but not the monovalent cation tetramethylammonium (Hrabetová et al., 2009). Increased diffusion of calcium ions could have an effect similar to the application of extracellular high divalent solutions. Future work is necessary to test these hypotheses.

PNNs are complex structures and are likely to have diverse roles in neuronal physiology and plasticity (Tsien, 2013). The present study shows that PNNs increase the gain of the inhibitory neurons they surround and could therefore increase synaptic inhibition in the brain. In the auditory system, neurons must fire rapidly, reliably, and precisely in order to process small differences in timing between the two ears. It is not surprising then, that so many neurons in the auditory brainstem are coated with PNNs. It remains to be seen whether the disruption of PNNs that can occur in disease underlies auditory pathology.

\section{References}

Ashida G, Carr CE (2011) Sound localization: Jeffress and beyond. Curr Opin Neurobiol 21:745-751. CrossRef Medline

Balmer TS, Carels VM, Frisch JL, Nick TA (2009) Modulation of perineuronal nets and parvalbumin with developmental song learning. J Neurosci 29:12878-12885. CrossRef Medline

Bertolotto A, Manzardo E, Guglielmone R (1996) Immunohistochemical mapping of perineuronal nets containing chondroitin unsulfated proteoglycan in the rat central nervous system. Cell Tissue Res 283:283-295. Medline

Blosa M, Sonntag M, Brückner G, Jäger C, Seeger G, Matthews RT, Rübsamen R, Arendt T, Morawski M (2013) Unique features of extracellular matrix in the mouse medial nucleus of trapezoid body-implications for physiological functions. Neuroscience 228: 215-234. CrossRef Medline

Blosa M, Sonntag M, Jäger C, Weigel S, Seeger J, Frischknecht R, Seidenbecher Cl, Matthews RT, Arendt T, Rübsamen R, Morawski M (2015) The extracellular matrix molecule brevican is an integral 
component of the machinery mediating fast synaptic transmission at the calyx of Held. J Physiol 593:4341-4360. CrossRef

Brückner G, Brauer K, Härtig W, Wolff JR, Rickmann MJ, Derouiche A, Delpech B, Girard N, Oertel WH, Reichenbach A (1993) Perineuronal nets provide a polyanionic, glia-associated form of microenvironment around certain neurons in many parts of the rat brain. Glia 8:183-200. CrossRef Medline

Bryant HL, Segundo JP (1976) Spike initiation by transmembrane current: a white-noise analysis. J Physiol 260:279-314. Medline

Bukalo O, Schachner M, Dityatev A (2001) Modification of extracellular matrix by enzymatic removal of chondroitin sulfate and by lack of tenascin-R differentially affects several forms of synaptic plasticity in the hippocampus. Neuroscience 104:359-369. Medline

Carstens KE, Phillips ML, Pozzo-Miller L, Weinberg RJ, Dudek SM (2016) Perineuronal nets suppress plasticity of excitatory synapses on CA2 pyramidal neurons. J Neurosci 36:6312-6320. CrossRef Medline

Carulli D, Pizzorusso T, Kwok JC, Putignano E, Poli A, Forostyak S, Andrews MR, Deepa SS, Glant TT, Fawcett JW (2010) Animals lacking link protein have attenuated perineuronal nets and persistent plasticity. Brain 133:2331-2347. CrossRef Medline

Celio MR, Spreafico R, De Biasi S, Vitellaro-Zuccarello L (1998) Perineuronal nets: past and present. Trends Neurosci 21:510-515. Medline

Chattopadhyaya B, Di Cristo G, Higashiyama H, Knott GW, Kuhlman SJ, Welker E, Huang ZJ (2004) Experience and activity-dependent maturation of perisomatic GABAergic innervation in primary visual cortex during a postnatal critical period. J Neurosci 24:9598-9611. CrossRef Medline

Dityatev A, Brückner G, Dityateva G, Grosche J, Kleene R, Schachner M (2007) Activity-dependent formation and functions of chondroitin sulfate-rich extracellular matrix of perineuronal nets. Dev Neurobiol 67:570-588. CrossRef Medline

Fawcett J (2009) Molecular control of brain plasticity and repair. Prog Brain Res 175:501-509. CrossRef Medline

Frankenhaeuser B, Hodgkin AL (1957) The action of calcium on the electrical properties of squid axons. J Physiol 137:218-244. Medline

Frischknecht R, Heine M, Perrais D, Seidenbecher Cl, Choquet D, Gundelfinger ED (2009) Brain extracellular matrix affects AMPA receptor lateral mobility and short-term synaptic plasticity. Nat Neurosci 12:897-904. CrossRef Medline

Galtrey CM, Asher RA, Nothias F, Fawcett JW (2007) Promoting plasticity in the spinal cord with chondroitinase improves functional recovery after peripheral nerve repair. Brain 130:926-939. CrossRef Medline

García-Alías G, Barkhuysen S, Buckle M, Fawcett JW (2009) Chondroitinase $A B C$ treatment opens a window of opportunity for taskspecific rehabilitation. Nat Neurosci 12:1145-1151. CrossRef Medline

Giger RJ, Hollis ER 2nd, Tuszynski MH (2010) Guidance molecules in axon regeneration. Cold Spring Harb Perspect Biol 2:a001867. CrossRef Medline

Gogolla N, Caroni P, Lüthi A, Herry C (2009) Perineuronal nets protect fear memories from erasure. Science 325:1258-1261. CrossRef Medline

Harauzov A, Spolidoro M, DiCristo G, De Pasquale R, Cancedda L, Pizzorusso T, Viegi A, Berardi N, Maffei L (2010) Reducing intracortical inhibition in the adult visual cortex promotes ocular dominance plasticity. J Neurosci 30:361-371. CrossRef Medline

Härtig W, Brauer K, Brückner G (1992) Wisteria floribunda agglutininlabelled nets surround parvalbumin-containing neurons. Neuroreport 3:869. Medline

Härtig W, Derouiche A, Welt K, Brauer K, Grosche J, Mäder M, Reichenbach A, Brückner G (1999) Cortical neurons immunoreactive for the potassium channel Kv3.1b subunit are predominantly surrounded by perineuronal nets presumed as a buffering system for cations. Brain Res 842:15-29. Medline
Härtig W, Singer A, Grosche J, Brauer K, Ottersen OP, Brückner G (2001) Perineuronal nets in the rat medial nucleus of the trapezoid body surround neurons immunoreactive for various amino acids, calcium-binding proteins and the potassium channel subunit Kv3.1b. Brain Res 899:123-133. Medline

Henze DA, Buzsáki G (2001) Action potential threshold of hippocampal pyramidal cells in vivo is increased by recent spiking activity. Neuroscience 105:121-130. Medline

Hermann J, Pecka M, von Gersdorff H, Grothe B, Klug A (2007) Synaptic transmission at the calyx of Held under in vivo like activity levels. J Neurophysiol 98:807-820. CrossRef Medline

Hille B (2001) Ion channels of excitable membranes, Ed 3. Sunderland, MA: Sinauer Associates.

Hrabetová S, Masri D, Tao L, Xiao F, Nicholson C (2009) Calcium diffusion enhanced after cleavage of negatively charged components of brain extracellular matrix by chondroitinase ABC. J Physiol 587:4029-4049. CrossRef Medline

Huang $\mathrm{H}$, Trussell L (2011) KCNQ5 channels control resting properties and release probability of a synapse. Nat Neurosci 14:840847. CrossRef Medline

Johnston J, Postlethwaite M, Forsythe ID (2009) The impact of synaptic conductance on action potential waveform: evoking realistic action potentials with a simulated synaptic conductance. $\mathrm{J}$ Neurosci Methods 183:158-164. CrossRef Medline

Kim J, Renden R, von Gersdorff H (2013) Dysmyelination of auditory afferent axons increases the jitter of action potential timing during high-frequency firing. J Neurosci 33:9402-9407. CrossRef Medline

Kirkwood A, Bear MF (1994) Hebbian synapses in visual cortex. J Neurosci 14:1634-1645. Medline

Kochlamazashvili G, Henneberger C, Bukalo O, Dvoretskova E, Senkov O, Lievens PM, Westenbroek R, Engel AK, Catterall WA, Rusakov DA, Schachner M, Dityatev A (2010) The extracellular matrix molecule hyaluronic acid regulates hippocampal synaptic plasticity by modulating postsynaptic L-type $\mathrm{Ca}(2+)$ channels. Neuron 67:116-128. CrossRef Medline

Kopp-Scheinpflug C, Tolnai S, Malmierca MS, Rübsamen R (2008) The medial nucleus of the trapezoid body: comparative physiology. Neuroscience 154:160-170. CrossRef Medline

Kuhlman SJ, Lu J, Lazarus MS, Huang ZJ (2010) Maturation of GABAergic inhibition promotes strengthening of temporally coherent inputs among convergent pathways. PLoS Comput Biol 6:e1000797. CrossRef Medline

Kuhlman SJ, Olivas ND, Tring E, Ikrar T, Xu X, Trachtenberg JT (2013) A disinhibitory microcircuit initiates critical-period plasticity in the visual cortex. Nature 501:543-546.

Massey JM, Hubscher CH, Wagoner MR, Decker JA, Amps J, Silver J, Onifer SM (2006) Chondroitinase ABC digestion of the perineuronal net promotes functional collateral sprouting in the cuneate nucleus after cervical spinal cord injury. J Neurosci 26:4406-4414. CrossRef Medline

Mataga N, Mizuguchi Y, Hensch TK (2004) Experience-dependent pruning of dendritic spines in visual cortex by tissue plasminogen activator. Neuron 44:1031-1041. CrossRef Medline

McGee AW, Yang Y, Fischer QS, Daw NW, Strittmatter SM (2005) Experience-driven plasticity of visual cortex limited by myelin and Nogo receptor. Science 309:2222-2226. CrossRef Medline

Mease RA, Famulare M, Gjorgjieva J, Moody WJ, Fairhall AL (2013) Emergence of adaptive computation by single neurons in the developing cortex. J Neurosci 33:12154-12170. CrossRef Medline

Miyata S, Nishimura Y, Hayashi N, Oohira A (2005) Construction of perineuronal net-like structure by cortical neurons in culture. Neuroscience 136:95-104. CrossRef Medline

Morawski M, Reinert T, Brückner G, Wagner FE, Arendt TH, Tröger W (2004) The binding of iron to perineuronal nets: a combined nuclear microscopy and Mössbauer study. Hyperfine Interact 159:285291. CrossRef

Morawski M, Reinert T, Meyer-Klaucke W, Wagner FE, Tröger W, Reinert A, Jäger C, Brückner G, Arendt T (2015) lon exchanger in the brain: quantitative analysis of perineuronally fixed anionic bind- 
ing sites suggests diffusion barriers with ion sorting properties. Sci Rep 5:16471. CrossRef Medline

Murakami T, Tsubouchi M, Tubouchi Y, Taguchi T, Ohtsuka A (1994) The occurrence of neurons with strongly negatively charged surface coats in mammalian, avian, reptilian, amphibian and piscine brains. Acta Med Okayama 48:195-197. Medline

Myers AK, Ray J, Kulesza RJ Jr (2012) Neonatal conductive hearing loss disrupts the development of the Cat-315 epitope on perineuronal nets in the rat superior olivary complex. Brain Res 1465:3447. CrossRef Medline

Oertel D (1999) The role of timing in the brain stem auditory nuclei of vertebrates. Annu Rev Physiol 61:497-519. CrossRef Medline

Pizzorusso T, Medini P, Berardi N, Chierzi S, Fawcett JW, Maffei L (2002) Reactivation of ocular dominance plasticity in the adult visual cortex. Science 298:1248-1251. CrossRef Medline

Pizzorusso T, Medini P, Landi S, Baldini S, Berardi N, Maffei L (2006) Structural and functional recovery from early monocular deprivation in adult rats. Proc Natl Acad Sci U S A 103:8517-8522. CrossRef Medline

Romberg C, Yang S, Melani R, Andrews MR, Horner AE, Spillantini MG, Bussey TJ, Fawcett JW, Pizzorusso T, Saksida LM (2013) Depletion of perineuronal nets enhances recognition memory and long-term depression in the perirhinal cortex. J Neurosci 33:70577065. CrossRef Medline

Schneider CA, Rasband WS, Eliceiri KW (2012) NIH Image to ImageJ: 25 years of image analysis. Nat Methods 9:671-675. Medline

Seeger G, Brauer K, Härtig W, Brückner G (1994) Mapping of perineuronal nets in the rat brain stained by colloidal iron hydroxide histochemistry and lectin cytochemistry. Neuroscience 58: 371-388. Medline

Shen Y, Tenney AP, Busch SA, Horn KP, Cuascut FX, Liu K, He Z, Silver J, Flanagan JG (2009) PTPsigma is a receptor for chondroitin sulfate proteoglycan, an inhibitor of neural regeneration. Science 326:592-596. CrossRef Medline
Slee SJ, Higgs MH, Fairhall AL, Spain WJ (2005) Two-dimensional time coding in the auditory brainstem. J Neurosci 25:9978-9988. CrossRef Medline

Sonntag M, Blosa M, Schmidt S, Rübsamen R, Morawski M (2015) Perineuronal nets in the auditory system. Hear Res 329:21-32. CrossRef Medline

Srinivasan J, Schachner M, Catterall WA (1998) Interaction of voltage-gated sodium channels with the extracellular matrix molecules tenascin-C and tenascin-R. Proc Natl Acad Sci U S A 95:15753-15757. Medline

Street SE, Manis PB (2007) Action potential timing precision in dorsal cochlear nucleus pyramidal cells. J Neurophysiol 97:4162-4172. CrossRef Medline

Takesian AE, Hensch TK (2013) Balancing plasticity/stability across brain development. In: Progress in brain research (Michael $\mathrm{M}$. Merzenich MN, Thomas MVV, eds), pp 3-34. New York: Elsevier.

Taschenberger H, von Gersdorff H (2000) Fine-tuning an auditory synapse for speed and fidelity: developmental changes in presynaptic waveform, EPSC kinetics, and synaptic plasticity. J Neurosci 20:9162-9173. Medline

Taschenberger H, Leão RM, Rowland KC, Spirou GA, von Gersdorff $\mathrm{H}$ (2002) Optimizing synaptic architecture and efficiency for highfrequency transmission. Neuron 36:1127-1143. Medline

Trussell LO (1997) Cellular mechanisms for preservation of timing in central auditory pathways. Curr Opin Neurobiol 7:487-492. Medline

Trussell LO (1999) Synaptic mechanisms for coding timing in auditory neurons. Annu Rev Physiol 61:477-496. CrossRef Medline

Tsien RY (2013) Very long-term memories may be stored in the pattern of holes in the perineuronal net. Proc Natl Acad Sci U S A 110:12456-12461. CrossRef Medline

Vorobyov V, Kwok JC, Fawcett JW, Sengpiel F (2013) Effects of digesting chondroitin sulfate proteoglycans on plasticity in cat primary visual cortex. J Neurosci 33:234-243. CrossRef Medline 